\title{
Correlation of cervical pap smears with histopathological diagnosis in cervical lesions
}

\author{
Ruksana Farooq ${ }^{1 *}$, Azhar-un-Nisa Quraishi' ${ }^{1}$, Shahida Mohammad ${ }^{2}$
}

${ }^{1}$ Department of Obstetrics and Gynecology, SKIMS, Soura, Srinagar, Jammu and Kashmir, India
${ }^{2}$ Department of Obstetrics and Gynecology, Government Medical College, Srinagar, Jammu and Kashmir, India

Received: 15 October 2021

Revised: 18 November 2021

Accepted: 19 November 2021

\section{*Correspondence:}

Dr. Shahida Mohammad,

E-mail: shahidamohammad03@gmail.com

Copyright: () the author(s), publisher and licensee Medip Academy. This is an open-access article distributed under the terms of the Creative Commons Attribution Non-Commercial License, which permits unrestricted non-commercial use, distribution, and reproduction in any medium, provided the original work is properly cited.

\begin{abstract}
Background: Cervical cancer is the most common genital cancer in India. In India alone,almost,130000 new cases occur with the death toll of 70000 everywhere. Objective of current study was correlation of pap smear with histopathological diagnosis.

Methods: A retrospective study was conducted in tertiary care hospital in 130 sexually active women. Pap smears were taken and histopathological diagnosis was performed in all such patients

Results: From pap smear findings, out of 130 patients, maximum number of cases, 74 (56.9\%) were categorized as. Out of epithelial cell abnormality, ASCUS was seen in 25 patients (10.2\%), LSIL in 17 patients (13.1\%), HSIL in 11 patients (8.5\%). SCC was seen in 2 patients (1.5\%) and adenocarcinoma in 1 patient $(0.8 \%)$. From cervical biopsy reports, 51 cases $(39.2 \%)$ were diagnosed as chronic cervicitis, 34 cases $(26.2 \%)$ were diagnosed as chronic cervicitis with squamous metaplasia, CIN I in 31 patients $(23.8 \%)$, CIN II in 8 patients $(6.2 \%)$ and CIN III in 3 patients $(2.3 \%)$, squamous cell carcinoma in 2 patients $(1.5 \%)$ and adenocarcinoma in 1 patient $(0.8 \%)$. The sensitivity, specificity, positive predictive value, negative predictive value and accuracy of pap smear test was $91.1 \%, 82.4 \%, 73.2 \%, 94.6 \%$ and $85.4 \%$, respectively.

Conclusions: Pap smear has excellent correlation with histopathological diagnosis. Therefore it should be encouraged as effective tool for cervical cancer screening program to reduce incidence and mortality caused by cervical cancer.
\end{abstract}

Keywords: Adenocarcinoma, Histopathology, Pap smear, cytology

\section{INTRODUCTION}

Carcinoma of cervix is the second most common cancer among women world-wide, after breast cancer. Cervical cancer is the most common genital cancer in India. In India alone, almost, 130000 new cases occur with the death toll of 70000 everywhere. ${ }^{1}$ Cervical cancer is a preventable disease due to long standing preinvasive stage. The usual 10-20 years from preinvasive lesion to highly malignant cancer provides rationale for prevention, early detection and treatment of cervical cancer. Screening program has reduced incidence of cervical cancer by $80 \%$ and its mortality by $60 \%$.Pap smear is a primary screening test for cervical cancer. ${ }^{2,3}$ It is simple, non-invasive and effective method for detection of cervical cancer. Cervical biopsy is gold standard but it is invasive and gives histopathological diagnosis. ${ }^{4}$ This study was conducted to correlate cervical pap smear with histopathological diagnosis in cervical lesions. 


\section{METHODS}

This was a retrospective study conducted in the department of Obstetrics and Gynecology, SKIMS, Soura, Srinagar over a period of two years from March 2019 to March 2021.A total of 130 Patients were selected that had undergone pap test and cervical biopsy. Detailed clinical parameters like lecourrhea, pain lower abdomen, menorrhagia, postcoital bleeding and intermenstrual bleeding were studied. The pap smears were taken with ayers spatula, spread on a glass slide and fixed immediately with $95 \%$ alcohol. Staining was done using pap stains. Reporting was done as per Bethesda classification system. Similarly cervical biopsies and hysterectomy specimens were taken from same patients. The cytological reporting was compared with histopathological diagnosis.

\section{Inclusion criteria}

Sexually active women with complaints of leucorrhea, lower abdominal pain, postcoital bleeding, postmenstrual bleeding and menorrhagia were included in study.

\section{Exclusion criteria}

Women with no sexual exposure, pregnant and lactating women and unmarried women were excluded from study.

\section{Statistical methods}

The recorded data was compiled and entered in a spreadsheet (Microsoft excel) and then exported to data editor of SPSS Version 20.0 (SPSS Inc., Chicago, Illinois, USA). Statistical software SPSS (version 20.0) and Microsoft excel were used to carry out the statistical analysis of data. Continuous variables were expressed as Mean \pm SD and categorical variables were summarized as percentages. Diagnostic accuracy (sensitivity, specificity, positive predicted value, negative predicted value and accuracy) of cytology was obtained taking histopathological diagnosis as gold standard.

\section{RESULTS}

A total of 130 patients were taken in study. Most of the patients were in the age group of greater than 45 years $(40.8 \%)$, with a mean of $41.9 \pm 7.82$ years. Most women were multipara with parity of three found in $41.5 \%$. The most common chief complaint among patients was white discharge per vaginum in 63 patients $(48.5 \%)$, pain lower abdomen in 37 patients $(28.5 \%)$, intermenstrual bleeding in 27 patients $(20.8 \%)$, menorrhagia in 19 patients $(14.6 \%)$, postcoital bleeding in 14 patients $(10.8 \%)$ and postmenopausal bleeding in 4 patients $(3.1 \%)$ (Table 1$)$. From pap smear findings, out of 130 patients, maximum number of cases, 74 (56.9\%) were categorized as NILM (negative for intraepithelial malignancy. Out of epithelial cell abnormality, ASCUS (atypical squamous cell of uncertain significance) was seen in 25 patients $(10.2 \%)$,
LSIL (low grade squamous intraepithelial lesion in 17 patients (13.1\%), HSIL (high grade squamous intraepithelial lesion in 11 patients $(8.5 \%)$. SCC (squamous cell carcinoma) was seen in 2 patients $(1.5 \%)$ and adenocarcinoma in 1 patient $(0.8 \%)$ (Table 2$)$.

Table 1: Baseline characteristics of study patients.

\begin{tabular}{|c|c|c|c|}
\hline Parameter & & $\mathbf{N}$ & $\%$ \\
\hline \multirow{5}{*}{ Age (years) } & $30-34$ & 14 & 10.8 \\
\hline & $35-39$ & 27 & 20.8 \\
\hline & $40-44$ & 36 & 27.7 \\
\hline & $\geq 45$ & 53 & 40.8 \\
\hline & Mean \pm SD (range) & $2(3$ & $-48)$ \\
\hline \multirow{5}{*}{ Parity } & Nullipara & 4 & 3.1 \\
\hline & Para 1 & 16 & 12.3 \\
\hline & Para 2 & 21 & 16.2 \\
\hline & Para 3 & 54 & 41.5 \\
\hline & $\geq$ Para 4 & 35 & 26.9 \\
\hline \multirow{6}{*}{$\begin{array}{l}\text { Chief } \\
\text { Complaints }\end{array}$} & $\begin{array}{l}\text { Whitish discharge per } \\
\text { vaginum }\end{array}$ & 63 & 48.5 \\
\hline & Pain lower abdomen & 37 & 28.5 \\
\hline & Intermenstrual bleeding & 27 & 20.8 \\
\hline & Menorrhagia & 19 & 14.6 \\
\hline & Postcoital bleeding & 14 & 10.8 \\
\hline & Postmenopausal bleeding & 4 & 3.1 \\
\hline
\end{tabular}

Table 2: Cytological diagnosis of study patients.

\begin{tabular}{|lll|}
\hline Cytological diagnosis & N & $\%$ \\
\hline NILM & 74 & 56.9 \\
\hline ASCUS & 25 & 19.2 \\
\hline LSIL & 17 & 13.1 \\
\hline HSIL & 11 & 8.5 \\
\hline SCC & 2 & 1.5 \\
\hline Adenocarcinoma & 1 & 0.8 \\
\hline Total & 130 & 100 \\
\hline
\end{tabular}

From cervical biopsy reports, out of 130 specimens, 51 cases $(39.2 \%)$ were diagnosed as chronic cervicitis, 34 cases $(26.2 \%)$ were diagnosed as chronic cervicitis with squamous metaplasia. CIN I was seen in 31 patients (23.8\%), CIN II was seen in 8 patients $(6.2 \%)$ and CIN III was seen in 3 patients (2.3\%). Malignancy was seen in 3 patients $(2.3 \%)$, out of which squamous cell carcinoma was seen in 2 patients $(1.5 \%)$ and adenocarcinoma in 1 patient $(0.8 \%)$ (Table 3). From our study, strong correlation was found between pap smear findings and cervical biopsy reports, thereby confirming role of pap smear test in screening of cervical lesions. The sensitivity, specificity, positive predictive value, negative predictive value and accuracy of pap smear test was $91.1 \%, 82.4 \%, 73.2 \%, 94.6 \%$ and $85.4 \%$, respectively (Table 6). 


\section{DISCUSSION}

In the present study, maximum cases were in the age group $>45$ years $(40.8 \%)$ and $40-44$ years $(27 \%)$, which was comparable to study of Joshi et al where maximum patients were in the age group of $41-50$ years $(50 \%){ }^{5}$

Table 3: Histopathological diagnosis of study patients.

\begin{tabular}{|lll|}
\hline Histopathological diagnosis & $\mathbf{N}$ & $\%$ \\
\hline Chronic cervicitis & 51 & 39.2 \\
\hline $\begin{array}{l}\text { Chronic cervicitis with squamous } \\
\text { metaplasia }\end{array}$ & 34 & 26.2 \\
\hline CIN I & 31 & 23.8 \\
\hline CIN II & 8 & 6.2 \\
\hline CIN III & 3 & 2.3 \\
\hline SCC & 2 & 1.5 \\
\hline Adenocarcinoma & 1 & 0.8 \\
\hline Total & 130 & 100 \\
\hline
\end{tabular}

Similarly reported by Benedet et al and by Algotar et al. ${ }^{6,7}$ The most common complaint in our study was white discharge per vaginum $(48.5 \%)$ of patients followed by pain lower abdomen $(28.5 \%)$ of patients (Table 1$)$. This was comparable to study conducted by Bindroo et al,where white discharge per vaginum was seen in $46 \%$ of patients and pain lower abdomen in $30 \%$ of patients. ${ }^{8}$ In our study, NILM was seen in $56.9 \%$ of patients which was comparable to study conducted by Joshi et al where NILM was seen in $64 \%$ of cases. Similarly Atla et al and Alokananda et al reported NILM in 53\% and 55\%, respectively. ${ }^{1,9,10}$ In contrast Malpani et al found NILM in $97.96 \%$ of cases that can be attributed to sample size discrepancy. ${ }^{11}$ In our study, epithelial cell abnormality was seen in $43.1 \%$ of cases. This was comparable to study conducted by Bindro et al where Epithelial cell abnormality was seen in $40.4 \%$ of cases. ${ }^{8}$

Table 4: Cyto-histopathological correlation of pap smears and cervical biopsies.

\begin{tabular}{|c|c|c|c|c|c|c|c|}
\hline \multirow[b]{2}{*}{$\begin{array}{l}\text { Cytological } \\
\text { diagnosis }\end{array}$} & \multicolumn{7}{|c|}{ Histopathological diagnosis } \\
\hline & $\begin{array}{l}\text { Chronic } \\
\text { cervicitis }\end{array}$ & $\begin{array}{l}\text { Chronic cervicitis } \\
\text { with squamous } \\
\text { metaplasia }\end{array}$ & CIN I & CIN II & CIN III & SCC & Adenocarcinoma \\
\hline NILM & 48 & 22 & 4 & - & - & - & - \\
\hline ASCUS & 3 & 11 & 10 & 1 & - & - & - \\
\hline LSIL & - & 1 & 16 & - & - & - & - \\
\hline HSIL & - & - & 1 & 7 & 3 & - & - \\
\hline SCC & - & - & - & - & - & 2 & - \\
\hline Adenocarcinoma & - & - & - & - & - & - & 1 \\
\hline
\end{tabular}

Table 5: Correlation between pap smear and histopathological diagnosis.

\begin{tabular}{|llll|}
\hline Observation & \multicolumn{3}{l|}{ Histopathological diagnosis } \\
& Positive & Negative & Total \\
\hline Positive & 41 & 15 & 56 \\
\hline Negative & 4 & 70 & 74 \\
\hline Total & 45 & 85 & 130 \\
\hline
\end{tabular}

Table 6: Diagnostic accuracy of pap smear taking histopathological diagnosis as gold standard.

\begin{tabular}{|lll|}
\hline Variable & Value & $95 \%$ CI \\
\hline Sensitivity & 91.1 & $79.3-96.5$ \\
\hline Specificity & 82.4 & $72.9-89.2$ \\
\hline PPV & 73.2 & $60.4-83.1$ \\
\hline NPV & 94.6 & $86.9-97.9$ \\
\hline Accuracy & 85.4 & $78.3-90.5$ \\
\hline
\end{tabular}

Also Joshi et al reported Epithelial cell abnormality in $36 \%$ of cases. ${ }^{5}$ In our study LSIL and HSIL were seen in $13.1 \%$ and $8.5 \%$ of cases respectively, which was comparable to study of Bindro et al where LSIL and HSIL were seen in 14.8 and $7.6 \%$ of cases, respectively. ${ }^{8}$ In our study Squamous cell carcinoma and adenocarcinoma were reported in $1.5 \%$ and $0.8 \%$ cases, respectively (Table 2) which was comparable to study of Joshi et al where SCC and adenocarcinoma was seen in $2 \%$ cases only. ${ }^{1}$ Similar study conducted by Bodal and Brar reported adenocarcinoma in $2 \%$ cases only. ${ }^{12}$ In our study $94.5 \%$ cases of NILM on pap smear correlated with histopathology (Table 4), which was comparable to studies by Atla et al $(93 \%)$ and Alakananda et $\operatorname{al}(91 \%) .{ }^{9,10}$ In our study, out of 17 cases of LSIL, $94.1 \%$ were diagnosed as CIN I, which was comparable to study conducted by Bindroo et al where LSIL correlated with CIN I in $91.8 \%$ of cases. ${ }^{8}$ Similarly $90.9 \%$ cases of HSIL correlated with cervical biopsy. This was similar to reports of Atla et al where $99 \%$ of HSIL cases correlated correctly. ${ }^{9}$ On pap smear, 2 cases and 1 case were diagnosed as squamous cell carcinoma and adenocarcinoma, respectively, which showed $100 \%$ correlation on histopathology. Similarly Bindroo et al reported $100 \%$ correlation in diagnosis of squamous cell carcinoma and adenocarcinoma on pap smear and histopathology (Table 4). ${ }^{8}$ The sensitivity of pap test in our study was comparable to Ashmita et al (90.24\%), specificity was comparable to Mallur et al (80\%). ${ }^{13},{ }^{14} \mathrm{In}$ our study, the overall accuracy was comparable to Atla et al $(83.33 \%)$, Patil $(82.1 \%)$ and Joshi et al $(80 \%) .^{9,11,5}$ This study shows good correlation between pap smear and cervical histology. 


\section{Limitations}

The main limitation of the study was that only symptomatic women were taken in study, asymptomatic women were not included. Apart from this, since it was a hospital based study, the referrals were to higher centers were biased.

\section{CONCLUSION}

The pap smear screening should be carried out in all sexually active women. Pap smear is cost-effective, easily available and non-invasive method of cervical cancer screening. It has excellent correlation with histopathological diagnosis. Therefore it should be encouraged as effective tool for cervical cancer screening program to reduce incidence and mortality caused by cervical cancer.

Funding: No funding sources Conflict of interest: None declared

Ethical approval: The study was approved by the Institutional Ethics Committee

\section{REFERENCES}

1. Cervical cancer estimated incidence, mortality and prevalence worldwide in 2012. Available at: https://gco.iarc.fr/. Accessed on 20 August 2021.

2. Sachan PL, Singh M, Patil ML, Sachan R. A study on cervical cancer screening using pap smear test and clinical correlation. Asia Pac J Oncol Nurs. 2018;5: 337-41.

3. Ferlay J, Shin HR, Bray F, Forman D, Mathers C, Parkin DM. Estimates of worldwide burden of cancer in 2008. Int J Cancer. 2010;127:2893-917.

4. Shaw PA. The history of cervical screening I:The Pap Test. J Soc Obstet Gynaecol Can. 2000;22:110-4.

5. Joshi C, Kajur P, Thakur N. Correlation of pap smear and colposcopy in relation to Histopathological findings in Detection of premalignant lesions of cervix in a Tertiary care centre. Int J Sci Stud. 2015; 3:55-60.

6. Benedet JL, Boyes DA, Nicholas TM, Milner A.Colposcopic evaluation of patients with abnormal cervical cytology. Obstet Gynecol Survey. 1976; 31(11):815-7.
7. Algotar K, Nalwade A, Sachdev S. Predictive value of colposcopy in cervical cancer screening. Bombay Hosp J. 2004;4603:1-9.

8. Bindroo MG. Correlation of cervical pap smear with histopathological diagnosis in cervical lesions: A 2 years retrospective study. Obstet Gynecol Survey. 2005;45(9):572-9.

9. Atla BL, Uma P, Shamili M, Kumar SS. Cytological patterns of cervical pap smears with Histopathological correlation. Int J Res Med Sci. 2015,3:1911-6.

10. Alakananda SU, Biswas I. Histopathological correlation with cervical cytology. IOSR J Dent Med Sci. 2016;15:53-8.

11. Malpani G, Agarwal P, Varma AV. Cervical pap smear study and detection of abnormal epithelial lesions and determination of its accuracy by cytohistological correlation in patients of tertiary care teaching hospital in central India. Int $\mathbf{J}$ Reprod Contracept Obstet Gynecol. 2016;5:2312-6.

12. Bodal VK, Brar BK. Correlation of pap smear with histopathological findings in malignant and non malignant lesions of cervix. Glob J Med Res E Gynecol Obstet. 2014;14:19-23.

13. Ashmita D, Shakuntala PN, Rao SR. Comparison and correlation of pap smear,colposcopy and histopathology in symptomatic women and suspicious looking cervix in a tertiary care hospital. Int $\mathbf{J}$ Health Sci Res. 2013;3:50-9.

14. Mallur PR, Desai BR, Anita D. Sequential Screening with cytology and colposcopy in detection of cervical Neoplasia. J South Asian Fed Obstet Gynecol. 2009;1:45-8.

15. Patil S, Patil A, Solanke P. Cytological screening for early diagnosis of cervical Intraepithelial Neoplasia and early carcinoma of cervix. Int J Sci Res Publ. 2015;5:51-6.

16. Goel P, Devi L, Saha PK, Takkar N, Huria A, Dua D. Maternal and perinatal outcome in pregnancy with epilepsy. Internet J Gynecol Obstet. 2006;5:45-9.

17. Raji C, Sekar D. Prospective study of fetomaternal outcome in epilepsy in pregnancy in a tertiary care hospital. Int J Reprod Contracept Obstet Gynecol. 2017;6(11):5055-9.

Cite this article as: Farooq R, Quraishi A, Mohammad S. Correlation of cervical pap smears with histopathological diagnosis in cervical lesions. Int J Reprod Contracept Obstet Gynecol 2021;10:4478-81. 